\title{
Defining an Urban Image with a Comprehensive Graphics System
}

\author{
W. MAX LUCAS, LOIS E. GREENE, and RICHARD L. BRANHAM \\ University of Kansas \\ USA
}

\section{INTRODUCTION}

The image established by an urban area can have a profound effect upon the future well being of that area. Economic development and other forms of growth can be encouraged or discouraged by the image of an area. In addition, the way the image is projected is of major importance in how the image is perceived by others.

It is the purpose of this paper to describe a process by which the image of an area can be defined and a comprehensive graphics system can be designed to project that image. Techniques are presented for encouraging citizen participation in the definition process. Professional survey and inventory procedures used to study the image of an urban area are described. Methods to establish the extent of the graphics system, categories of data collection, a discussion of sign types, as well as the hierarchy of geographical space and the development of the comprehensive graphics design matrix are presented.

The application of comprehensive graphics systems and their support of the image of particular urban areas are compared and discussed through the presentation of examples from Europe and Asia, as well as a discussion of a system now being developed with both directional signage and promotional materials for a historical county and its cities in Kansas.

\section{RATIONALE FOR THE PROJECT}

The concept of using graphics to project a particular urban image or to identify territory is not new. Indeed, such techniques can be found throughout history and have been utilized in many areas of the world. In addition, there are many ways to determine an image for an urban area. The image can be based upon any one of a number of factors such as history, climate, sports teams or other factors perceived important by the citizens of the area. In addition, urban areas are usually composed of a hierarchy of sub-areas such as state, county, city, district and attraction, and each may choose to project its own distinct image. In any event, it is the mental image that citizens hold of their environments that defines the image of the area. However, the projection of an urban area's image to others is equally important and that task can be aided by the implementation of a well-designed, comprehensive graphics system.

In the case of Siena, Italy, the graphic symbol used for identification date from medieval times. The very simple shield design of pure white over black, with no additional adornment was established as the identifying mark for Siena over 900 years ago and is still being used. That mark provides identification for the Comune de Siena (the "county" or citystate of Siena) as well as the city of Siena and is readily recognized, not only in Italy, but throughout the world. The shield of Siena is strikingly different from the shields of other medieval cities in Italy. The shield identifies and distinguishes Siena as a different city from other cities. The Siena shield is displayed on every item of commune or city property. It is present on the doors of municipal vehicles, on city trash receptacles, on fountains and on governmental buildings.

In addition, the individual urban districts of Siena (contradas) have identifying marks. In Siena, the concept of identity for a contrada is made to distinguish each contrada or district from another. Equally important is the perception of the contrada's image held by the inhabitants of each contrada. The contrada establishes a home or a placeness for each inhabitant and remains so even when the person leaves the contrada. Each contrada is identified by name (such as

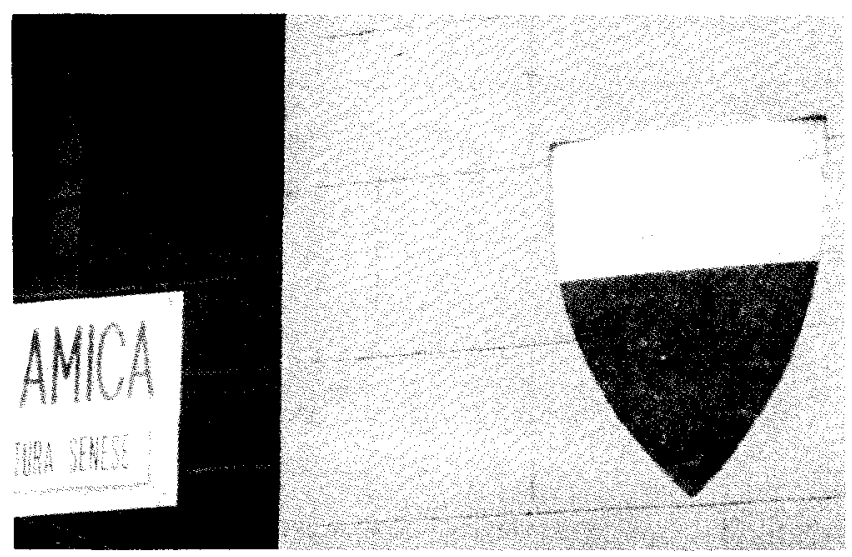

Fig. 1. Shield of Siena 
turtle, dragon, snail, etc.) which is also the name of the identifying mark or symbol for that contrada. The contrada mark is used to identify mail boxes, churches, businesses, residences, and many other elements within the boundaries of the contrada. Children born within a contrada are baptized at the contrada fountain which usually incorporates a sculpture of the contrada mark. On ceremonial days, contrada flags displaying the contrada mark and the contrada colors are flown from buildings within the contrada. In many instances both the Siena shield and the contrada mark are displayed together indicating pride of belonging to both the city of Siena and to a particular contrada within the city. This hierarchy of identification of a county or city and then the districts within that city is one of the better examples of urban identity marks to be found.

On the other side of the world lies Hong Kong. The Urban Council of Hong Kong comprises both the city and island of Hong Kong, the city of Kowloon as well as the New Territories. The graphics image for this area serves a function entirely different from that of the graphic image of Siena.

Hong Kong is an ancient city. Very little indication of territorial marks survive from the early days of the city, however. Hong Kong does have narrow streets with open market places, all of which display signs with both graphic as well as written images. At the same time, Hong Kong is a city with new and exciting architecture designed by some of the most prominent architects of today. It is a city of many beautiful parks and public plazas, as well as having extremely densely populated areas. Hong Kong is also the commercial center of Asia and is well known for its business center and for its trading on the world market.

Because of the various and disparate images projected by the activities within the Urban Council of Hong Kong, a simple but elegant identifying mark was designed to project something other than the energetic and hectic image of Hong Kong. To that end a stylized outline of an orchid-like flower which grows on trees within the city has been chosen as the mark for the Urban Council. This mark appears on all property of the Urban Council and serves as identifier for parks, vehicles, buildings, trash containers, urban maps, and other items of property within the city. The mark is well designed and projects an image of a "city of flowers" or a "peaceful place to visit" or even "a city that cares about its appearance". In any case, it appears that this mark was carefully designed to project a particular image rather than simply to identify territory or property.

As can be seen from the examples above, an identifying mark for an urban area can serve a number of functions. Certainly it can identify territory or property associated with the government of the area. The mark will readily identify ownership of property. The mark can define territory and act as a visual clue to others that this territory belongs to the user of the mark, and visitors are notified that they fall under the regulations of that territory. It can be a symbol of identification and of belonging for citizens of the area. In that manner

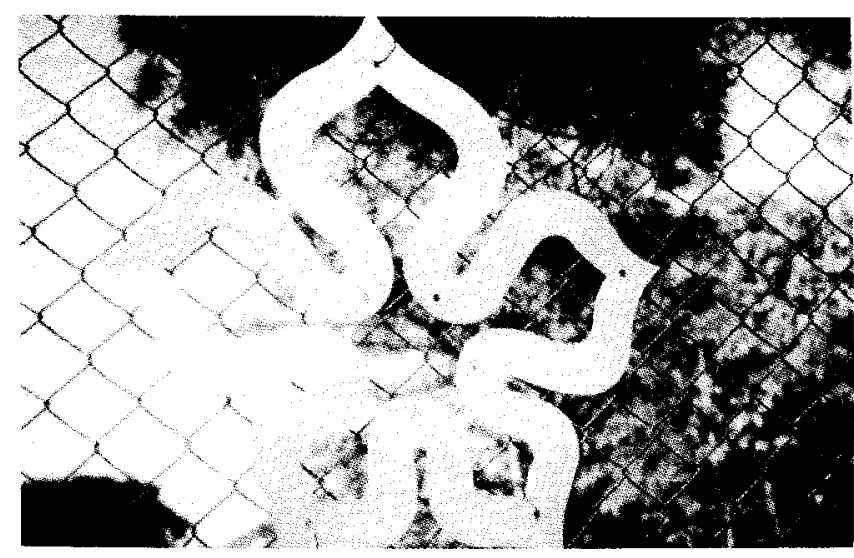

Fig. 2. Flower mark of the Urban Council of Hong Kong

a mark can be an indication of pride one shows for belonging to a particular group. Finally, a mark can project a particular image of an area to the general public. In any event, a graphic symbol for an urban area must be carefully designed and represent the desires of the population of that area. And then, with a carefully designed coordinated graphics system, that mark can establish a particular image and project that image through a signage system.

\section{DEVELOPMENT OF A COMPREHENSIVE GRAPHICS SYSTEM}

Through a state initiative in the State of Kansas called Signage Tourism 2000, monies were allocated during the 1980 's to encourage towns to add to their tourist-related signage. Today the Department of Transportation continues to fund state-wide signage identifying parks and historical places of interest to visitors.

The Chamber of Commerce in Lawrence, Kansas saw an opportunity to bring together the diverse elements within Douglas County to promote greater cooperation between the cities in order to improve the "image" of all the cities within the county through signage. The Chamber of Commerce recognized the need to promote inter-personal cooperation among the citizens of the county and, therefore, a task force was established to formulate and recommend changes to the signage to aid in guiding potential visitors to places of interest within the county. A design team was engaged to develop a process to accomplish the above goals and to produce a comprehensive graphics system.

Because of the emphasis on community involvement during the development of the process, an early decision by the design team was to form an advisory Steering Committee composed of members representing cities and townships within the county to work with the design team in providing ideas and support. Membership on the Steering Committee was based upon an individual's past interests in historic preservation and promotion of his/her own communities as well as past service on county-wide boards and commissions. The initial discussions between the design team and the 
Steering Committee centered around the accepted perceptions of the strengths of the city, its history, attractions and events sponsored and supported by the citizens, businesses and educational institutions. Research in various areas, such as tourism and perception, was shared with the Steering Committee.

The design team presented the idea that a systematic development of promotional materials should occur along with any signage. Based on perceptual research the design team believed that the two systems would function together to better aid the visitor in understanding where he/she was located in the county, and what places and events were available in the county. A comprehensive overview of promotional materials from all communities in the county was undertaken. Figure 3 shows a model suggesting how a visitor would access information about the County (brochures and maps), and how the initial promotional materials would be coordinated through design elements with the signage throughout the County to reinforce in the visitor's mind a wayfinding model.

A schema was developed to explain the overall organization of the comprehensive graphics system. The county-wide directional signage was designed to incorporate the regulations of the Federal Traffic Control Manual which would blend the design of the signs for the Interstates highways, through to the signs indicating the county and cities. Further, a hierarchy of information was established for each unit, including the county, city, district, and attraction levels. The Steering Committee was presented with the schema for their reactions and suggestions as were citizens at meetings the design team had throughout the County. Following acceptance by the Steering Committee and after receiving suggestions from citizens throughout the County, the design team prepared designs for the directional signage program and appropriate promotional materials.
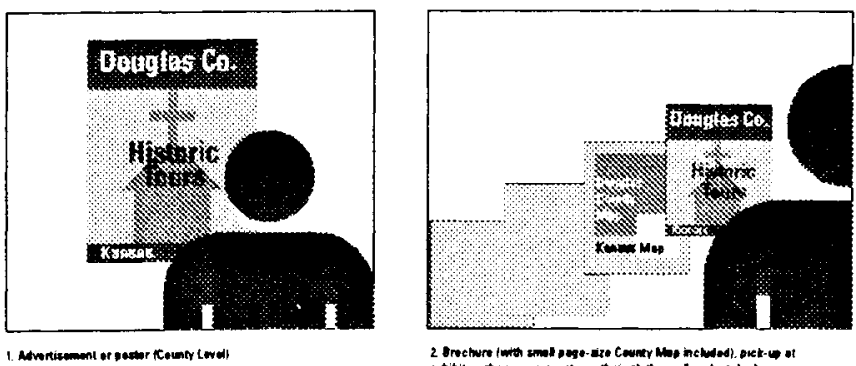

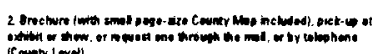

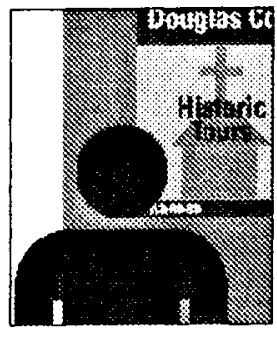

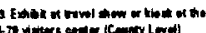

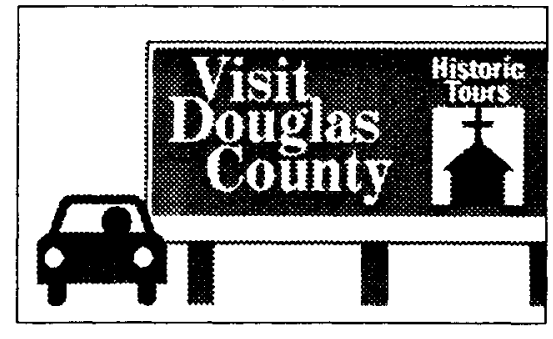

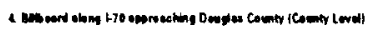

\section{DETERMINING AN URBAN IMAGE}

Early in the process, team members scheduled public meetings in each city within the county and gave presentations at civic organizations. These public meetings introduced attendees to the concept of graphic symbols or "marks" to identify areas and property associated with the county, cities or townships. A process to encourage public meetings to discuss identity marks for their areas was commenced and an interaction between these public groups and the design team began to define possible images that lead to the design of identifying marks for each city and township in the county.

The process of working with the community committees was accomplished by employing an iterative design process, to develop each design idea. The design team tested each idea with the community committees and then evaluated the test data for input into the next iteration. This was a cyclic process of designing, then testing, then evaluation which was repeated until an acceptable solution was reached. All of these people working together from the beginning aided in more accurate and productive decision-making. The iterative process clarified issues and helped to evolve solutions that more citizens could find acceptable and meaningful. Designers and citizen/users in this process worked together and learned from each other.

The design team concentrated on the development of an identifying mark for the small city of Baldwin City, Kansas which is located in the center of Douglas County. The present Baldwin City, which has a population of 10,000 , grew from the incorporation of four smaller towns, all of which were settled in the mid 1800s. Geographically, the area is noted for rolling hills, forests and good agricultural land. During the 1800 s, however, there were few trees. Much of the area was covered in tall grasses. This history of Baldwin City encompasses, as does the history of Douglas County, the two major
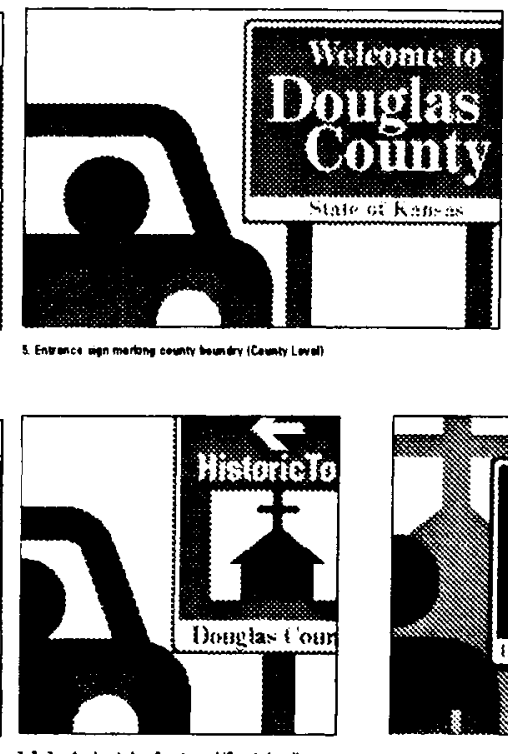

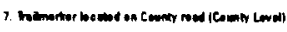

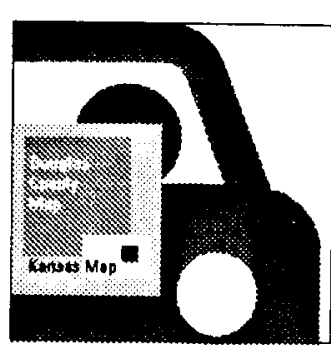

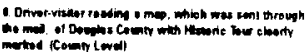
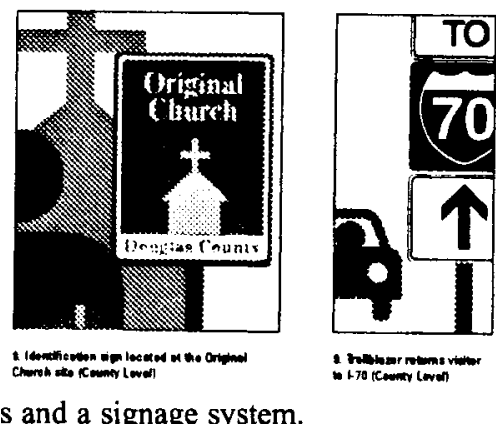

Fig. 3. County-level schematic diagram showing possible coordination of promotional materials and a signage system.

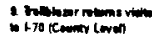




\section{Schema for signage program - a diagram}

A. Entrance signs

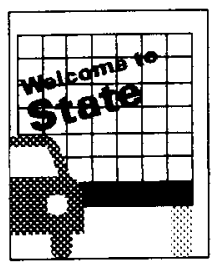

I. County level

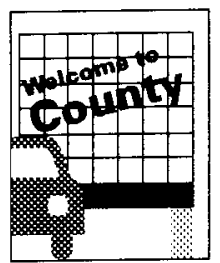

II. City level
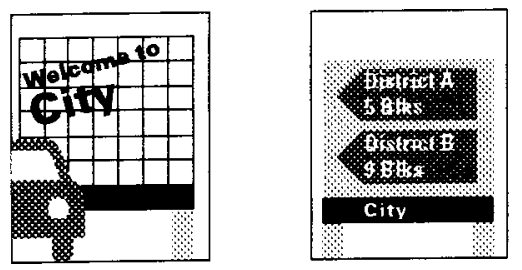

III. District level
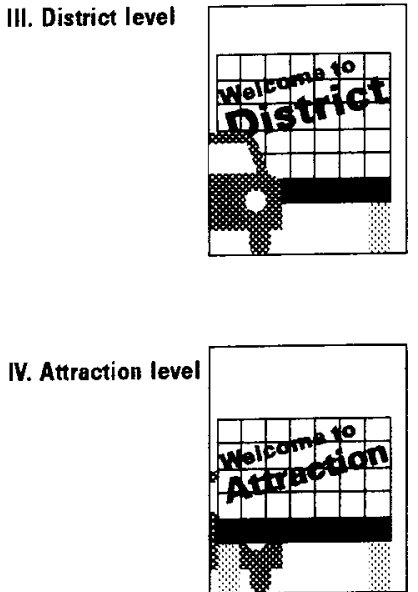

B. Directional signs
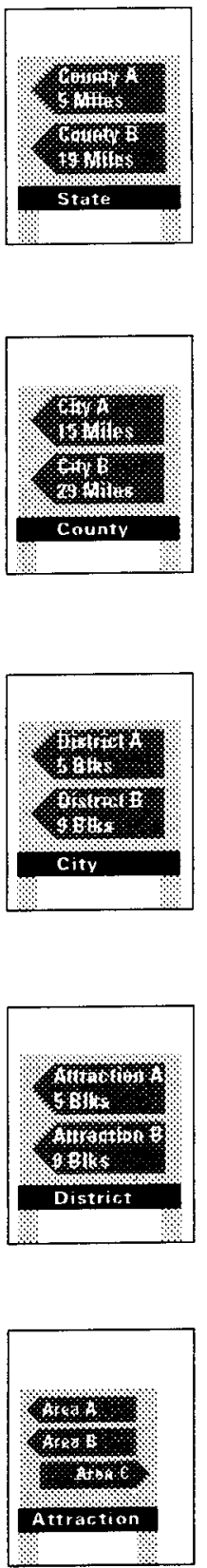
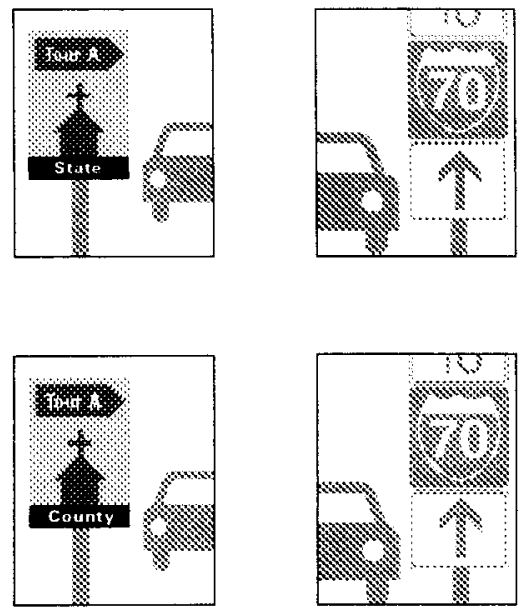

Trailblazers

E. Identification

signs
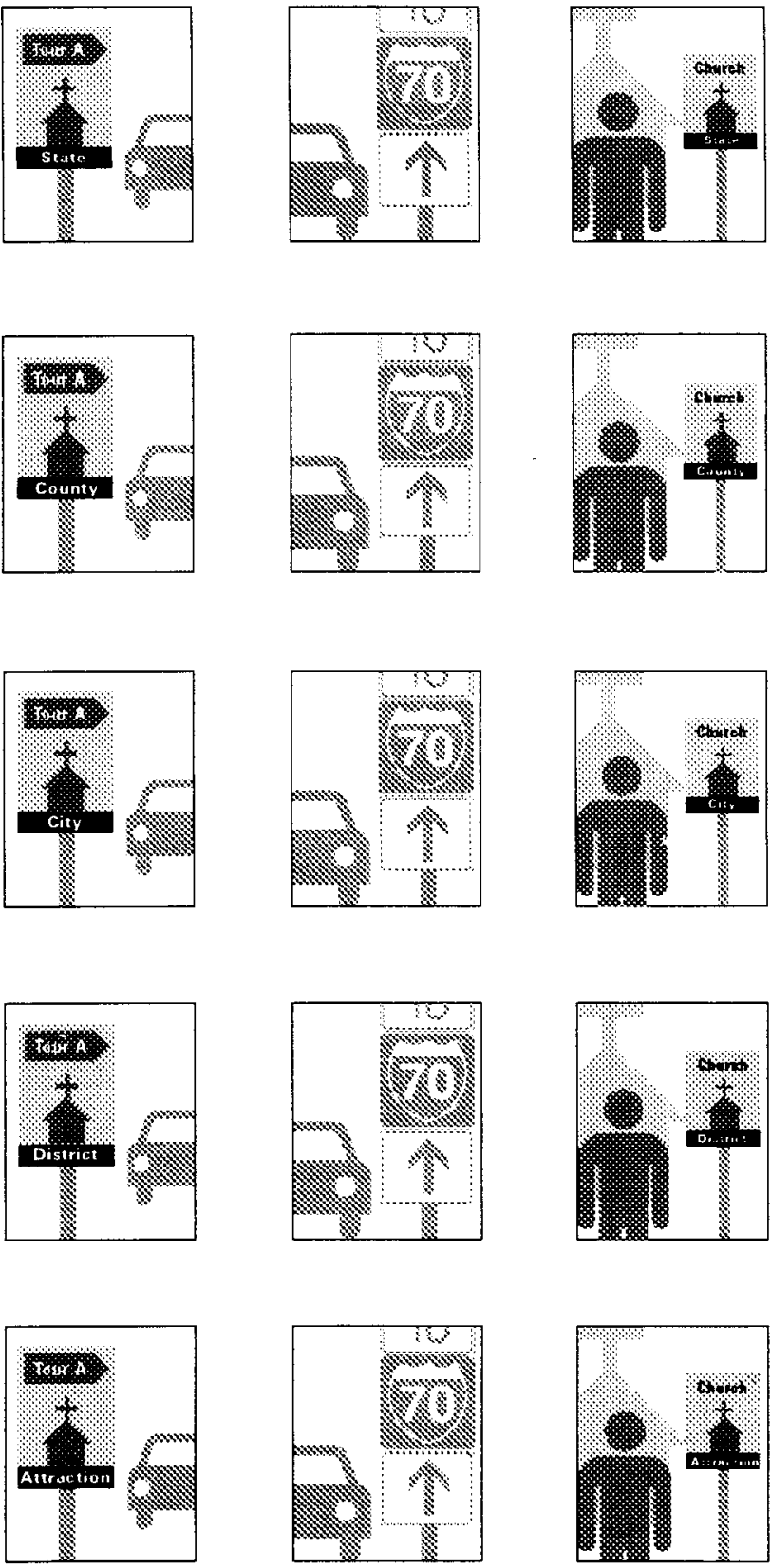

Fig. 4. Schema for signage system showing geographical hierarchy and sign types.

issues and events of the mid 1800s in the United States, that of westward expansion and the dispute over slavery.

The Kansas Territory was a battle ground for those opposed to and those in favor of slavery. One such battle was fought near the present site of Baldwin City in 1856. The location of that battle was near the settlement of Black Jack in an area of oak trees called Black Jack oaks. Concurrent to the conflict over slavery in Douglas County and Baldwin City, the beginnings of the movement of large numbers of people to the western parts of the continent occurred. Baldwin City sits on the Santa Fe Trail and there are several attractions from this period in the city's history that remain, including sites of blacksmiths' shops, mills, wells and ruts or swales left by the migrating wagons on the grass-covered plain. Those ruts remain visible today. Later in the 1800s native limestone buildings were erected along the Trail for purposes of education and commerce. The first four year college in Kansas was founded in 1958. Its first building, called "Old Castle", is such a limestone structure and now houses a museum with many artifacts from the 
early days of the city and the westward movement.

Meetings with the design team and the citizens of Baldwin City produced in-depth discussions about their history and the appropriate images that could represent that history and also what they perceived was important about their city today. Although the major festival in Baldwin City (called the Maple Leaf Festival) is enormously successful in attracting visitors, the majority of the citizens did not wish to emphasis the maple leaf as the city's image because it was limited to a specific event. In fact, the red maple trees were planted in the early 1900 s and did not represent to the citizens the importance of their history. The design team did develop specific marks (Figure 5) using the maple leaf (recent past and present day history) and the Black Jack oak leaf (past history) in two different configurations. The idea was to show the interrelationship of the histories over time.

What was generally agreed upon by the citizens as a subject in relation to a mark representing their city was the Santa Fe Trail. The strengths and characters of the first settlers seemed to be at the heart of what the citizens' groups
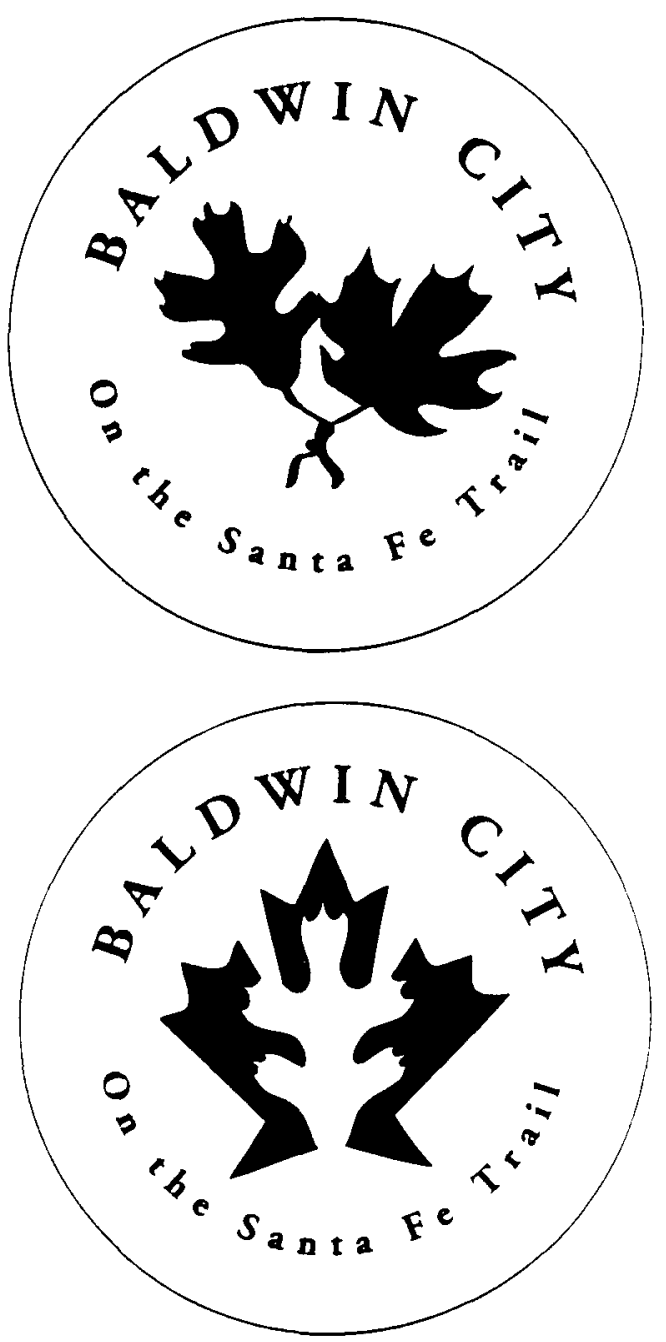

Fig. 5. Two marks for Baldwin City, Kansas using the combination of the red maple leaf and the Black Jack oak leaf. responded to when speaking of their past. Images of the Trail included pioneers, conestoga wagons and teams of oxen, wagon wheels and lanterns. Research showed, however, that one or more of these images was frequently used by other Kansas cities along the Trail, and the citizens of Baldwin City wanted a mark that was unique to their city. It should also be noted that while using an image suggested by historical events or places was important to the citizens, they also generally wished the mark to show an attitude or a reflection of the present. Figure 6 shows the mark accepted by the citizens which represents the grasses of the original site of Baldwin City and the wagon ruts left on the plain.

It is the plan of the city officials and planning commissioners to use the mark to identify city property (vehicles and the City Hall building), signs (directional and welcoming), as well as on promotional materials.

\section{CONCLUSIONS AND COMMENTS}

The development of a comprehensive graphics system for

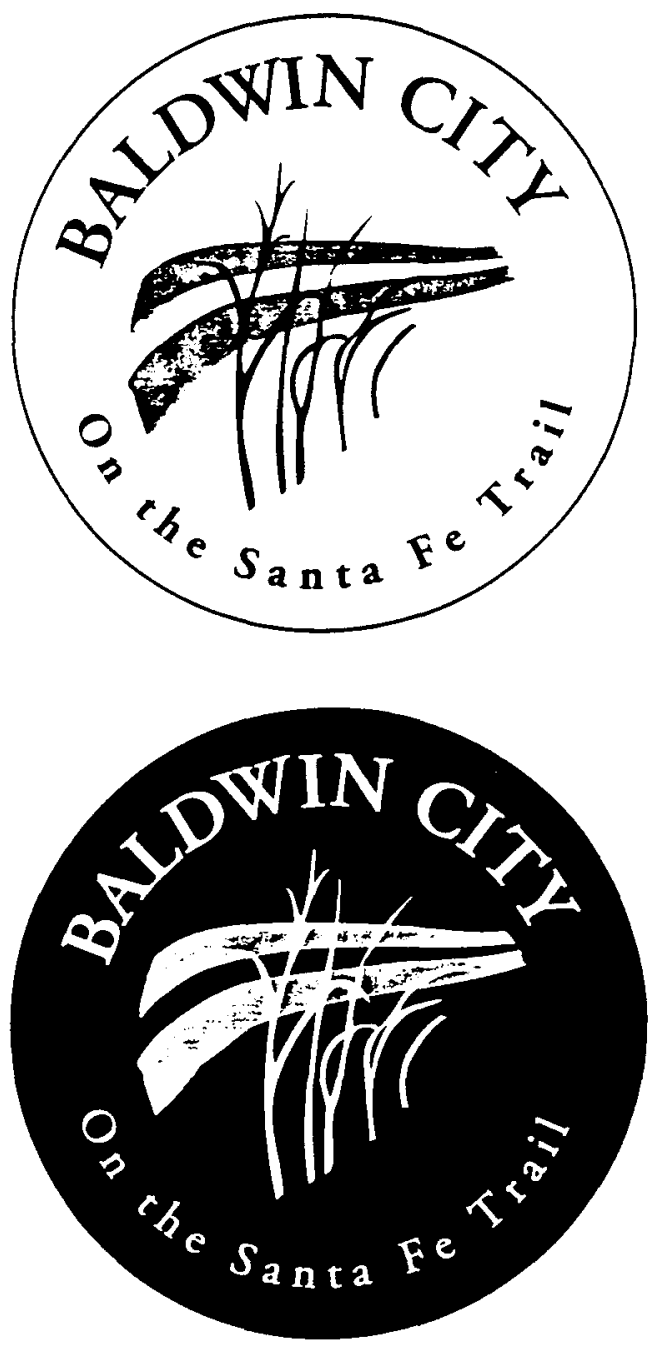

Fig. 6. The final mark for Baldwin City, Kansas in both positive and reverse values. 
this county in Kansas, has been an exciting and rewarding process. The decision to involve as many citizens of the county as possible in the process was a good one. Members of the Steering Committee bought into the process at an early date and were very helpful in disseminating information about the project to their constituents as well as answering questions about the intent of the project when such questions were asked.

This process has also had a major effect on the attitudes of the citizens and will certainly contribute to a better "image" for the county. As the graphics system is implemented, civic units will be installing signs and utilizing other promotional materials to direct visitors to other areas within the county. This has never happened in the past. In particular, the discussions concerning identifying marks has an enormous benefit in bringing diverse elements of the population together. These discussions, involving the history, heritage and environments of the county units and sub-units were very meaningful to the citizens of the county.

Of major importance is the fact that this project was accomplished only with wide community involvement in the process. From the hard working members of the Steering Committee working in their individual communities to the people who attended public meetings and then made their input known, this was truly a community project. And, as the system is implemented, a sense of pride and accomplishment will begin with those involved and, hopefully, extend to all of the citizens of the county.

\section{REFERENCES}

Signage Research:

Alexander, G. J. and Lunemfeld, J., Positive Guidance in Traffic ControlWashington, DC, Federal Highway Administration, 1975

Arthur, P. and Passini, R., Wayfinding: People, Signs, and Architecture McGraw-Hill Ryerson, Toronto, 1972

Branham, R., "Interface Design,"In Papers: The 1994 Conference on Design Education, Industrial Designers Society of America, 1994

Downs, R. M. and Stea, D., Maps in Minds: Reflections on Cognitive Mapping Harper and Row, New York, 1977

Garreau, J., Edge City, Doubleday, New York, 1991

Howett, C. M., "Systems, Signs, Sensibilities: Sources for a New Landscape Aesthetic", Landscape Journal, vol. 6, no. 7, University of Wisconsin System, Madison, 1987
"Notes Topward an Iconography of Regional Landscape Form, The Southern Model," Landscape Journal, vol. 4, no. 2, University of Wisconsin System, Madison, 1985

Jackson, J. B., A Sense of Place, A Sense of Time, Yale Unversity Press, New Haven, 1994

Discovering the Vernacular Landscape, Yale University Press, New Haven, CT, 1984

Jakle, J. A., The American Small Town, Archon Press, Hamden, CT, 1992

The Visual Elements of the Landscape, The University of Massachusetts Press, Amhurst, MA, 1987

The Tourist: Travel in Twentieth-Century North America, University of Nebraska Press, Lincoln, NE, 1985

Liebs, C. H., Main Street to Miracle Mile, Little, Brown and Company, Boston, 1985

Lynch, K.,The Image of the City, The M.I.T. Press, Cambridge, MA, 1960

MacCannell, D., The Tourist: A New Theory of the Leisure Class, Schocken Books, New York, 1976

Madelker, D. R. and Ewald, W. R., Street Graphics and the Law, Planners Press, American Planning Association, Washington, DC, 1988

Manual on Uniform Traffic Control Devices: for Streets and Highways, US Department of Transportation, Federal Highway Administration, Superintendent of Documents, Washington, DC, 1988

Meinig, C. W., The Interpretation of Ordinary Landscapes, Oxford University Press, New York, 1979

Passini, R., Wayfinding in Architecture, Von Nostrand Reinhold Company, New York, 1984

Pline, J., Traffic Engineering Handbook (4th Edition), PrenticeHall, Englewood Cliffs, NJ, 1984

Relph, E., Place and Placelessness, Pion Limited, London, 1976

Tuan, Yi-Fu, Space and Place: The Perspective of Experience, University of Minnesota Press, Minneapolis, 1977

Zonn, L. E., "Landscape Depiction and Perception: A Transactional Approach", Landscape Journal, vol. 3, no. 2, University of Wisconsin System, Madison, 1984

Historical Research:

David, Kenneth S., Kansas. A History, W.W. Norton \& Company, New York, 1984

Granzwa, Gregory M., The Santa Fe Trail Revisited, The Patrice Press, St. Louis, MO, 1989

Littner, Loren K., Bleeding Kansas. The Border War in Douglas and Adjacent Counties, Champion Publishing, Baldwin City, $\mathrm{KS}, 1987$

Simmons, Marc, Following the Santa Fe Trail, Ancient City Press, Santa Fe, NM, 1986

The Smithsonian Guide to Historic America: The Plains States, Steward, Tabori \& Chang: New York, 1990 